\title{
Ulva lactuca, A Source of Troubles and Potential Riches
}

\author{
Herminia Dominguez ${ }^{1}$ and Erwann P. Loret ${ }^{2, *(1)}$ \\ 1 Department of Chemical Engineering, Faculty of Science, Campus Ourense, University of Vigo, As Lagoas, \\ Galicia, 32004 Ourense, Spain; herminia@uvigo.es \\ 2 Aix Marseille University, Avignon University Centre National de la Recherche Scientifique (CNRS), \\ Institut de la Recherche et du Développement (IRD), Institut Méditerranéen de Biologie et \\ d'Ecologie (IMBE), Unité Mixte de Recherche CNRS 7263 IRD 237 Faculté St Jérôme, \\ Avenue Escadrille Normandie Niemen, Provence, CEDEX 20, 13397 Marseille, France \\ * Correspondence: erwann.loret@univ-amu.fr
}

Received: 17 April 2019; Accepted: 12 June 2019; Published: 14 June 2019

\begin{abstract}
Ulva lactuca is a green macro alga involved in devastating green tides observed worldwide. These green tides or blooms are a consequence of human activities. Ulva blooms occur mainly in shallow waters and the decomposition of this alga can produce dangerous vapors. Ulva lactuca is a species usually resembling lettuce, but genetic analyses demonstrated that other green algae with tubular phenotypes were $U$. lactuca clades although previously described as different species or even genera. The capacity for $U$. lactuca to adopt different phenotypes can be due to environment parameters, such as the degree of water salinity or symbiosis with bacteria. No efficient ways have been discovered to control these green tides, but the Mediterranean seas appear to be protected from blooms, which disappear rapidly in springtime. Ulva contains commercially valuable components, such as bioactive compounds, food or biofuel. The biomass due to this alga collected on beaches every year is beginning to be valorized to produce valuable compounds. This review describes different processes and strategies developed to extract these different valuable components.
\end{abstract}

Keywords: Ulva lactuca; green tides; virus; bioactives; biofuels; biorefinery

\section{Introduction}

Ulva lactuca is a macroalgae and belongs to the phylum Chlorophyta, described by Linnaeus in the Baltic Sea in the seventeenth century [1]. It is able to grow attached, sessile or free floating. The capacity to reproduce involving two methods, one being sexual and the other being from fragmentation of the thallus, is rarely observed in macroalgae [2], but this provides a capacity for it to rapidly proliferate by covering the water surface, decreasing the biodiversity even for other algae species [3]. Ulva lactuca is a polymorphic species with morphologies dependent on the degree of water salinity [4] or symbiosis with bacteria [1].

Macroalgae (or seaweeds) contain high amounts of carbohydrates (up to 60\%), medium/high amounts of proteins (10-47\%) and low amounts of lipids (1-3\%) with a variable content of mineral ash (7-38\%) [5]. With decreasing available land and fresh-water resources, the oceans have become attractive alternatives for the production of valuable biomass, comparable to terrestrial crops. Macroalgae cultivated under controlled and sustainable cultivation systems are probably the future method for supplying biomass to meet market development needs [6].

The high carbohydrate fraction includes a large variety of easily-soluble polysaccharides, such as laminarin, alginate, mannitol or fucoidan in brown types; starch, mannans and sulphated galactans in red types and Ulvan in green types [7]. Alginate, one of the main structural polymers of brown 
seaweeds, provides both stability and flexibility for the specimens exposed to flowing water, and is one of the industrially-relevant carbohydrate compounds found in seaweed biomass, as are other hydrocolloids, such as agar and carrageenans, which are commonly used as thickeners, gelling agents or emulsifiers. Various other non-carbohydrate products obtained from seaweeds include protein, lipids, phenols and terpenoids, and minerals such as iodine, potash and phosphorus-useful for human and animal nutrition [8]. The harvesting of macroalgae-a valuable raw material for food-before they beach could well be developed into an effective solution [9]. The interest of macroalgae in human nutrition is due to their high mineral concentrations (such as calcium, magnesium and potassium) and glutamic acid, which makes them also useful as taste enhancers. Algae could help to address one of the biggest challenges currently faced by the food industry, which is the ever growing human population. Algae are also a source of active principles largely unexplored for pharmaceutical products [7]. The gelling properties of polysaccharides are well known, and the therapeutic applications are in development [10,11]. Algal polysaccharides, pigments, proteins, amino acids and phenolic compounds are potential functional food ingredients for health maintenance and the prevention of chronic diseases, with increasing potential uses in pharmaceutical industries [12].

Ulva lactuca polymorphism dependent upon the environment led to the proposal that different species may exist, such as Ulva armoricana, rigida, prolifera, pertusa, fasciata or rotundata [1-4]. However, genetic analysis revealed that the different phenotypes observed were not based on genetic variations that would justify the existence of different species other than Ulva lactuca [13]. Taxonomy is challenging for the genus Ulva, which belongs to the phylum of Chlorophyta, constituting four traditional classes (Ulvophyceae, Trebouxiophyceae, Chlorophyceae and Chlorodendrophyceae) that evolved from unicellular marine planktonic prasinophyte algae in the Neoproterozoic [1]. Trebouxiophyceae and Chlorophyceae are found mainly in fresh water while Ulvophyceae colonize mainly shallow marine environments, similar to the Australian Collerpa that has colonized the Mediterranean Sea since 20 years ago. Linnaeus was the first to observe that Ulva lactuca could have different phenotypes with a tubular or a sheet-like tail, but taxonomists in the nineteenth century proposed that the tubular green algae were a distinct genus called Enteromorpha. However, molecular approaches demonstrated that Linnaeus was correct-Ulva and Enteromorpha are not distinct genera [13]. Different Ulva species are still described in the literature [14], but it turns out that reproduction is possible between these different "species", which therefore should be described as Ulva lactuca variants or clades.

Ulva blooms damage marine ecosystems and impair local tourism [9]. Ulva principally invades beaches, and its biodegradation can produce acidic vapors that have induced the death of animals and possibly humans since a horse was reported dead in 2009 on the Brittany coasts (located at the west of France) due to Ulva biodegradation [2]. The first Ulva bloom to be described was in Belfast (in the north of Ireland) at the end of the nineteenth century [15]. Ulva blooms were well-studied in the Laguna of Venice from 1930, with an unexplained decrease observed after 1990 [16,17]. Since 1980, Ulva blooms have been observed worldwide, from Galicia [18] to Tokyo Bay [19], including the American [20] and Australian continents [14]. However the largest events in the world to date have been the green tides observed in the Yellow Sea for ten consecutive years from 2007 and covering 10\% of the Yellow Sea [21]. In Europe, Brittany's north coasts have the biggest Ulva blooms [3]. While there is no doubt that Ulva blooms are due to human activities, it is generally farmers who are accused of being fully responsible for Ulva blooms because of their use of fertilizers [2,3]. However, for the green tides of Belfast and Venice, a correlation was established with human waste, due to an increase of workers [15] or tourists [17]. Furthermore, abundant sources of nitrogen and phosphorus are important for Ulva blooms, but phosphorus does not come from agricultural activity [2] and it is difficult to determine what part of nitrogen is due to fertilizers or human waste.

Preliminary experiments suggest that in the Mediterranean seas there is a virus that might provide a natural and ecological way to control Ulva blooms. Ulva blooms occur in the Mediterranean seas but disappear rapidly, and an enzyme activity related to giant viruses was observed in the bay of Marseille on denatured Ulva tissues (manuscript in preparation). Viruses are well known to participate in the 
control of microalgae blooms, but this is not demonstrated for macroalgae. Virus controls of microalgae blooms were recently observed in USA, with the two macroalgae Aureococcus anophagefferens inducing harmful bloom algae on the east coast [22] or Tetraselmis in Hawaii [23]. In these two cases, it was because of viruses that have been recently discovered and have been called giant viruses. Giant viruses were first discovered in amoebae [24]. While most viruses known over the past century have a size $<200 \mathrm{~nm}$, such as $160 \mathrm{~nm}$ for HIV or $20 \mathrm{~nm}$ for the smallest virus (Parvoviridae infecting pigs), giant viruses have a size of up to $1 \mu \mathrm{m}$. Since then, giant viruses have been discovered all across the world, infecting many species, particularly marine species [25].

Ulva contains commercially valuable components susceptible of being exploited for cosmetic, pharmaceutical, chemical, food and energy applications [7-26] and this review provides a background on products that might be obtained from Ulva, as well as the processing technologies used to date.

\section{Potential Riches of Ulva}

The integral valorization could represent a more sustainable approach—contributing to biorefinery processes-to valorize different constituents of Ulva offering alternatives to global environmental concerns. Two aspects favor this utilization, valuable products found in Ulva and its high productivity [7].

\subsection{Ulva Bioactive Compounds}

Ulva protein hydrolysates show antioxidant [27], angiotensin-converting enzyme (ACE)-inhibitory activity [28] and immunomodulatory effects [29]. Ulva has starch (1-4\%) as a reserve polysaccharide. Furthermore, Ulva has water-soluble and insoluble cellulose (38-52\%) corresponding to structural polysaccharides with a major component called Ulvan. Ulvans are sulphated heteropolysaccharides that contribute to the strength of the cell wall and give flexibility to Ulva, preventing Ulva desiccation for tides. Ulvan is up to $30 \%$ Ulva dry weight and contains mainly sulfonic acids, sulphated L-rhamnose, xylose and glucose. This polysaccharide and its oligosaccharides have anti-viral, anti-tumour, anti-coagulant, anti-lipidique, hepato protective, immuno-stimulating, anti-depressant and anti-anxiolytic activities [26, 30], and are increasingly requested for pharmaceutical and food applications. In addition, Ulvans are thermos reversible gels, with industrial applications in the chemical, pharmaceutical, biomedical and agricultural areas [26-30]. The commercial application of these gels is not yet as developed as other algal hydrocolloids [31]. However, interesting recent applications were reported with a composite material made of zinc oxide and calcium carbonate capped with Ulva polysaccharides for burn treatments [32]. Ulva carbohydrates can also be a carbon source for microbial production of biomaterials and building blocks to produce a range of chemicals and intermediates, such as organic acids, alcohols and biomaterials, but this market is still emerging [31].

Ulva has a unique fatty acid profile characterized by high levels of alpha linolenic acid (18:3w-3) and stearidonic acid (18:4 $\omega-3)$, the latter being an efficient precursor of eicosapentaenoic acid synthesis able to increase its human tissue levels [12,32]. In addition, Ulva contains phenolic, chlorophyll and carotenoids, which can be regarded as active free-radical scavengers [32]. The balanced content of $\mathrm{Na}$ and $\mathrm{K}$ (a ratio near to 1 ) is nutritionally beneficial [12]. A double-blinded versus placebo clinical trial showed that an Ulva water-soluble extract rich in oligo-elements (up to $50 \%$ and proteins of $10-20 \%$ ) had a beneficial effect on depression [30].

\subsection{Ulva for Food}

Ulva can be a source of essential amino acids—some of them, such as histidine, are found in levels comparable to those found in legumes and eggs [12]. Traditional food uses the whole Ulva, which is also spread on agricultural land or composted, but these solutions rapidly reach their limits and have little added value. To eat Ulva from green tide is safe, and it is a valuable nutriment based on its high content of proteins and $\mathrm{Fe}$, a good unsaturated lipid acid with a low-fat ratio and also has the presence of essential amino acids [21]. It is important, however, to verify that the concentrations of heavy metals, pesticides and polycyclic aromatic hydrocarbon is under regulation limits. Ulva 
from green tide could be used for a phytoremediation process of coastal water contaminated with bisphenol A [33]. The removal efficiency was positively influenced by light, nutrients and temperature, and salinity had no effect. This endocrine disruptor is rapidly and efficiently removed (more than 90\%) by fresh Ulva, whereas less than $5 \%$ could be removed from dead algal biomass.

Ulva can be used to feed fish or mollusks such as abalone and reinforce immunity [34]. Ulva is now used in integrated multi-trophic aquaculture systems as a partial replacement or supplement for the diet of juvenile Litopenaeus vannamei [35]. Harvested Ulva contains a large amount of proteins (up to $30 \%$ ) with a similar amino acid profile regarding commercial diet, but lower lipid levels (1.9\%) and no docosahexaenoic acid. The replacement of up to $25 \%$ of the commercial diet with fresh Ulva does not impact shrimp production and juvenile shrimps fed with Ulva have a better growth rate, a higher carotenoid content and a lower lipid content, found in examining shrimp carcasses [36].

Agricultural utilization of Ulva extracts was reported to enhance the vegetative growth in bean plants under drought stress, limiting the lipid peroxidation, increasing the phenolic content and probably contributing to the enhancement of the antioxidant enzymatic activity [37]. Ulva aqueous extracts enhance the vegetative growth under drought stress conditions and antioxidant potential for Salvia officinalis [38].

The utilization of a single fraction from Ulva biomass has been explored and this alternative is recommended when the biomass is destined to a high value added application. Acidic Ulva extracts were used to replace synthetic antioxidants and to protect different cosmetic products from oxidation [39]. Ulva aqueous extracts were used for the synthesis of gold and silver nanoparticles, with excellent biocompatibility on healthy cells and were highly cytotoxic against colorectal cancer cell lines HT-29 and Caco-2 [40]. A new food-grade protein extraction protocol was proposed from Ulva and showed high digestibility in simulated gastro-intestinal tests with a high antioxidant activity [27].

Ulvan, proteins and amino acids offer key opportunities to deliver multiple products and energy through a biorefinery process $[41,42]$. In a study to explore the use of offshore grown macroalgae as a sustainable feedstock for biorefineries, it was estimated that the annual productivity for Ulva ( $838 \mathrm{~g} \mathrm{C} / \mathrm{m}^{2}$ year) was higher than the global average $\left(290 \mathrm{~g} \mathrm{C} / \mathrm{m}^{2} \cdot\right.$ year) estimated for terrestrial biomass in the Middle East [43]. Similarly, it was found that Ulva can offer the best performance for a future biorefinery (15 g dry weight $/ \mathrm{m}^{2} \mathrm{~d}$ and $56 \mathrm{t} /$ ha year) [44].

\subsection{Production of Biofuels}

The valorization of Ulva biomass for the production of biofuels is attracting attention regarding three aspects: bioremediation for the ecosystem, a renewable energy source and economic savings [45]. Ulva can be an attractive source for biofuels, since its production does not require arable land and fertilizers. Ulva can grow in saline and waste water and has a higher ability in sequestering atmospheric $\mathrm{CO}_{2}$ than terrestrial energy crops [46]. In addition, the growth rate and productivity are high compared to those of land crops, and they can withstand harsh conditions to survive under stressful conditions. The most studied biofuels are biodiesel, bioethanol and biogas. Ulva could be an alternative to conventional oil crops because they contain oil, suitable for esterification/transesterification reactions for the biodiesel production [47]. For biodiesel production, hexane is one of the most suited, but other organic solvents or their mixtures have been proven suitable for oil extraction from Ulva biomass [48].

After harvest, Ulva biomass requires pre-treatment and/or saccharification and fermentation to be converted in bioethanol. Carbohydrates contain hexose sugars, which are suitable materials for fermentation in producing ethanol. The hydrolysis of these polysaccharides results in monosaccharides, such as glucose, mannose and galactose. These carbohydrates are easily fermentable compounds in anaerobic digestion, and their extraction makes possible a rapid degradation. The quantities of cellulose and lignin, normally abundant in terrestrial biomass, are generally lower in Ulva and in the macro algal genera because of the different structural requirements in aquatic environments [49].

The production of the third-generation bioethanol from marine macroalgae depends mainly on the development of an eco-friendly and eco-feasible pre-treatment (i.e., hydrolysis), a highly effective 
saccharification step, and, finally, an efficient bioethanol fermentation step. Ulva has cellulose as a main structural component. Different hydrolysis processes are suitable to maximize the extraction of fermentable sugars, such as thermochemical hydrolysis with diluted acids $\left(\mathrm{HCl}\right.$ and $\left.\mathrm{H}_{2} \mathrm{SO}_{4}\right)$ and a base $(\mathrm{NaOH})$, and hydrothermal hydrolysis followed by saccharification with different fungal strains, preferentially adapted to the medium $[50,51]$. Also chemical-free treatments are beneficial. Efficient solubilization (over $90 \%$ of sugars) can be achieved by hot-water treatment, and further hydrolysis using cellulases and bioconversion is favored by the lack of enzyme and microbial inhibitors. In addition, nutrient supplementation is not required. Hot-water treatment of Ulva, followed by hydrolysis with cellulases, makes possible the production of fermentation media that can be easily converted into acetone, butanol and ethanol by a microorganism such as Clostridium sp. [52].

Pre-treatment (physical, chemical, enzymatic) of macroalgae has considerable influence on the technical, economic and environmental sustainability of biogas production. Different pre-treatments of Ulva for biogas production were compared, and the reducing sugar yields demonstrate that enzymatic pre-treatment was superior to acid catalysis, thermos alkaline and ultra-sonication [53]. Ulva wastes collected from coastal areas can produce up to $166 \mathrm{~L} \mathrm{CH}_{4} / \mathrm{kg}$ volatile solids, whereas from food wastes and sewage sludge produce 350-380 L CH4/ $\mathrm{kg}$ volatile solids [54]. Higher biogas yields from Ulva biorefinery facilities yielded up to $271 \mathrm{~mL} \mathrm{CH}_{4} / \mathrm{kg}$ volatile solids (VS) in the range of methane production from cattle manure and crop land-based energies [41]. Enhanced bio methane production was observed in pretreated biomass and also in co-digestion processes [55].

A new promising alternative is the production of hydrogen from Ulva through dark or anaerobic fermentative technology [56,57]. The type of pre-treatment is important on the process performance, which can be improved with combinations of more than one pre-treatment and by the use of mixed anaerobic cultures [57].

\section{Processes and Strategies to Extract Component from Ulva}

Attempts to valorize Ulva collected on beaches leads to different problems, such as contamination with sands and pollutants from different origins. Industrial processes to produce artificially Ulva were developed to offer a production that is economically feasible and to attain a rational utilization of biomass following a biorefinery approach [58] since the sequential extraction of value-added products in a biorefinery is more efficient and viable [59]. The content of biologically active substances from natural origins depends on the site of the material collection, season and environmental conditions [60]. The medium nutrient content influences the fatty acid content; the $\omega-6 / \omega-3$ fatty acids ratio and also the chlorophyll, carotenoid and phenolic contents, and therefore the antioxidant and anti-inflammatory properties [32]. Also, the extraction technology and operational conditions have a marked influence on the yields and on the properties of the target compounds.

In order to selectively separate the target components from natural materials, a solvent extraction stage is required. The solvent extraction process is a mass transfer unit operation from a solid material with a solvent, which shows preferential affinity for the target solutes. Different variables are important in the final yield: particle size, solvent type, solvent to solid ratio and temperature. These operational conditions require individual or combined optimization in order to maximize yields, the extraction rate and the purity and properties of the products.

\subsection{Conventional Processes}

Solvents can be different, depending on the polarity and location of Ulva components. An aqueous solvent is suitable for polysaccharides, which is the most abundant fraction. Oil and pigment fractions require less polar solvents. Ulvan is usually extracted with a high yield from hot water and pressurized conditions [61]. Ulvans are thermally stable until approximately $180^{\circ} \mathrm{C}$ and present a high correlation between sulphate contents, their reducing power and their scavenging activity [62]. Water extraction of sulphated ulvan gives a product with a high antimicrobial activity against Enterobacter cloace and Escherichia coli [63]. A simple acidic method for extraction of Ulvan, with relatively low content of protein 
and high sulphate, is frequently used [30-64]. The properties and bioactivities of polysaccharides can be modulated by the extraction conditions; where rhamnose, glucuronic acid and glucose are the major monosaccharides obtained at $90^{\circ} \mathrm{C}$ with $0.01 \mathrm{M} \mathrm{HCl}$. Glucose is the major monomer at $150{ }^{\circ} \mathrm{C}$ with $0.1 \mathrm{M} \mathrm{HCl}$, and the sulphate content is also influenced by temperature and acid concentration. These parameters have an effect on functional properties, such as oil holding capacity, foaming capacity, stability, antioxidant activity and pancreatic lipase inhibition activity, which are modified [65].

Ulvan extraction is better with a coagulation-sedimentation process to shorten the filtration time of the residual biomass after the extraction step, although this chemical treatment reduced the yield due to coprecipitation [66]. The extraction of proteins and glycoproteins from Ulva is more efficient with lysis solutions containing surfactants than with buffer or deionized water alone. The proteins further hydrolyzed with protease confirmed the availability and the lack of cytotoxicity in Vero cells [60]. The selection of the solvent system for oil extraction is an important factor for fuel production. Simultaneous distillation and extraction to prepare volatile compounds (aldehydes, ketones, carboxylic acids, alcohols and hydrocarbons) show antimicrobial activities and inhibition of tyrosine kinase [67].

An important group of bioactive compounds are phenols, although their content in green algae is lower than in brown types. They are usually extracted with organic solvents, the type of solvent being important on the extract yields and properties. Conventional solvent extraction with methanol or ethanol is used for the extraction of phenols and ethyl acetate [37,68-71]. Higher yields of pigment and phenolic were obtained using 95\% ethanol, and carotenoids using acetone [32]. However, Ulva extracts show lower phenolic content and antioxidant properties compared with other natural materials or synthetic antioxidants [68].

\subsection{Biorefineries}

Ulva blooms represent a non-competitive green source for production of biofuels and other commodity materials. Abundant recent studies have confirmed the potential of Ulva for biorefinery. A general scheme following this strategy is shown in Figure 1. The major challenges for seaweed biorefineries are in relation with the production of high value products, the lower use of chemicals and waste disposal. The integrated biorefinery philosophy can solve different problems associated with the algal biomass conversion to bioenergy [46,72]. A marine biorefinery could be a solution to intensify Ulva production to obtain bioethanol [73]. The content of monosaccharides released by acid hydrolysis from different seaweeds was compared, revealing that Ulva has the highest economic potential [74].

Macro algal proteins and oligo- and polysaccharides are potential raw materials for the new generation of health ingredients having both techno- and bio-functional applications. Their extraction is usually placed in initial steps and the latter steps are usually those leading to biofuels [75]. The interest to extract valuable components present in the biomass in initial steps (phenolic and protein fractions) is to improve the economy of ethanol production and favor industrial implementation [76]. The utilization of the protein fractions would represent an opportunity for developing countries, which permanently face a protein shortage. The extraction processes should provide high protein yields, preserving the quality (amino acid profile and digestibility) and avoiding the presence of antinutritional compounds. Moreover, the extraction process should find its optimal placement in the whole bioethanol production chain.

Different washing steps have been proposed to remove salts for food applications [77]. After the evaporation of the washing water, the remaining solid biomass has a higher protein content from 11 to $24 \%$ and energy content from 20 to $50 \%$. Regarding Ulva phenotypes, the content in salts goes from $29 \%$ to $36 \%$ with $\mathrm{Na} / \mathrm{K}$ ratios from 1.1 to 2.2 and a maximum at $19 \%$ ulvan.

Mixing enzymatic and chemical extractions is proposed to maximize the extraction of high molecular ulvan fractions with gelling properties [78]. The adequate selection of the operating procedures (temperature and acid concentration) determines the chemical composition of ulvan and also the rheological and textural properties. Ulva insoluble dietary fiber shows high values in water 
holding capacity and oil holding capacity-comparable to other commercial fibers-which is suitable for the formulation of low caloric foods and in the stabilization of foods rich in fat and emulsion.

The feasibility was tested using Ulva residues remaining after the extraction of polysaccharides as an energetic source after a pre-treatment with hydrogen peroxide to enhance the efficiency of enzymatic hydrolysis and bioethanol yields [21]. The production of methane could be possible from the solid wastes of Ulva after sap extraction, Ulvan extraction and protein extraction, or after the sequential extraction of all these components. The highest methane yield of $408 \mathrm{~L} \mathrm{CH}_{4} / \mathrm{kg}$ VS was observed in sap and Ulvan-removed residue, suggesting that the high protein and sulphate content are major inhibitors in anaerobic digestion [59].

An interesting valorization is obtained from leftovers due to the Ulva polysaccharide extraction process using hot water and enzymes [79]. This material was added to potato chip dough at a level of $2.5 \%$. The water activity of chips with this Ulva extract was significantly less than other control chips without Ulva. The addition of Ulva leftovers increased the protein, ash and dietary fiber contents of baked potato chips. However, sensory scores showed that green algal addition produced an unacceptable color and strong seaweed flavor. The solid residue after the extraction of Ulva polysaccharides was also used to promote growth and to enhance non-specific immune and disease resistance enhancement against Vibrio parahaemolyticus in white shrimp Litopenaeus vannamei [80]. The animal mortality in the group fed with Ulva leftovers was lower compared with the control; the survival in the group fed with the polysaccharides extracted with cold water was $80 \%$. In the group feed with the polysaccharides extracted with hot water, it was $65 \%$, and in the control group, it was $40 \%$.

An original biorefinery approach is proposed to isolate sugars from Ulva [81]. The sugars in the biomass are solubilized by hot water treatment followed by enzymatic hydrolysis and centrifugation, resulting in a sugar-rich hydrolysate, and a protein-enriched extracted fraction, which could be advantageously used in animal feed compared to intact seaweeds. The content in essential amino acids and digestibility suggest a promising use in diets for monogastric animals. Reduction of the high content in minerals and trace elements may be required to allow a high inclusion level of Ulva products in animal diets. The hydrolysate is used successfully for the production of acetone, butanol, ethanol and 1,2-propanediol [82].

A multistep integrated process for the extraction of different products from Ulva provides opportunities to develop novel products and commercial applications [83]. The protein content is $11 \%$ in dry weight and protein digestibility is $86 \%$, indicating its suitability for use in food supplements. The cellulose extraction is the final step in this integrated approach and is the least affected by the up-stream treatments compared to other components. A similar strategy using Ulva leftovers after enzymatic saccharification proposes a use for aquaculture food [84]. During saccharification, the relative ash and carbohydrate content is reduced, but total nitrogen, total carbon and lipid content increase, making possible the survival and growth of bivalve spat and commercially valuable sea urchins over the course of three-week preliminary trials. Finally, another biorefinery approach integrates the hydrothermal liquefaction for biomass conversion to produce fuels (bio-oil and gas), aqueous fertilizers and remediation agents for domestic and marine culture effluents [85]. This technology is now used to transform macroalgae into aqueous phase products. Ulva offers the highest bio-oil yields. Hydrothermal liquefaction is effective for Ulva conversion, giving the highest bio-crude yields up to $29.9 \%$ and containing up to $60 \%$ of the total biomass energy content. 


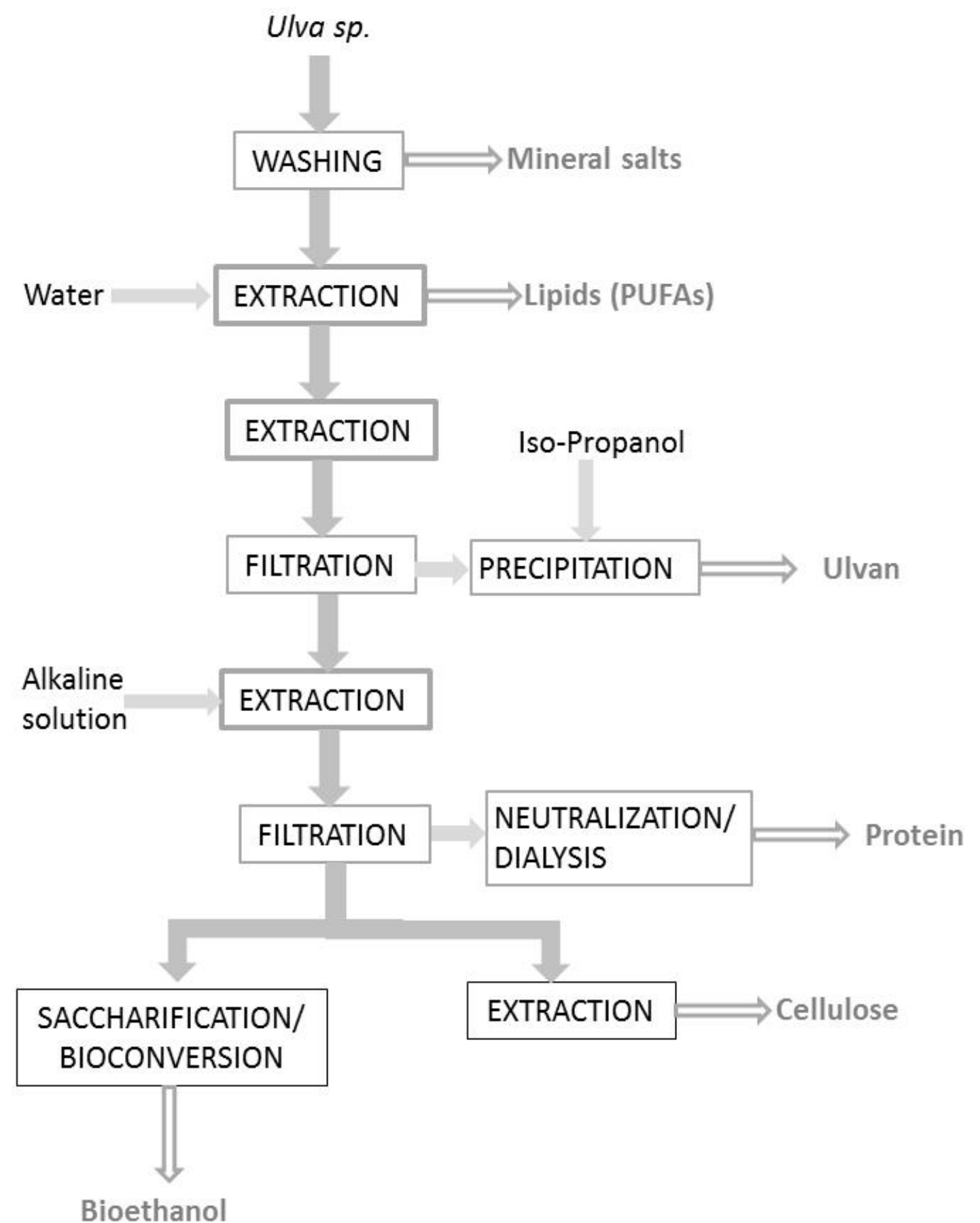

Figure 1. Simplified scheme of a biorefinery process according to final utilizations [83]. Different washing steps were proposed to remove salts. After evaporation of the washing water, the protein content increased by $11-24 \%$ and the energy content by $20-50 \%$. The adequate selection of the operating procedures (temperature, filtration and chemical treatment) determined the chemical composition of extracts.

\section{Emerging Technologies}

The development of food grade, scalable, efficient and environmentally friendly extraction processes is required to reduce the energy and solvent consumption. It is important also to provide a sustainable utilization of the raw material, and to avoid the generation of toxic and undesirable compounds in the final products. Regarding these three purposes, the development of new techniques 
and the use of water as solvent are particularly promising [82,83]. The principles of these new techniques are described in Figure 2.

\subsection{Pressurized Solvent Extraction}

This technique is performed at a high temperature and pressure to maintain the solvent in liquid state faster, and it requires lower amounts of solvent than traditional extraction techniques. This technique is also named accelerated solvent extraction or high pressure liquid extraction. The use of food-grade solvents, such as ethanol, converts this process into a green technique suitable for an industrial scale, and is useful for food processing. The pressurized ethanol extraction of bio actives from Ulva shows reduced and antiradical properties and also shows growth inhibition of the food spoilage bacteria, such as Escherichia coli, Micrococcus luteus and Brochothrix thermosphacta [85]. The accelerated solvent extraction of proteins is performed after pre-removal of lipids with hexane and phenol with $70 \%$ acetone [83].

When the solvent used is water, the technique is also called superheated water, subcritical water extraction, high temperature water extraction, pressurized hot water extraction or hot water extraction. Water is used in a liquid state under pressure between $100^{\circ} \mathrm{C}$ and the critical temperature of $374{ }^{\circ} \mathrm{C}$. Temperature has an important effect on yield and selectivity. The dielectric constant of water decreases with temperature, enabling the extraction of compounds with different polarities at different temperatures. High temperature also enhances diffusivities, making possible the transport of solutes from the solid matrix, and a compromise solution with thermal degradation has to be reached. The major variable during the operation is temperature, at $150{ }^{\circ} \mathrm{C}$ or higher, since water properties (especially the polarity) are significantly affected and polymeric substrates can be hydrolyzed because of the enhanced reactivity of water under these conditions. This strategy is attractive for the conversion of aquatic biomass, since the energy-intensive drying steps could be avoided [86]. Ulva hydrothermal liquefaction shows substantial variation in composition, with a bio crude oil yield from 9 to $20 \%$ [85]. The hydrothermal liquefaction with subcritical water $\left(300^{\circ} \mathrm{C}\right)$ is very important to extract organic solvents, such as methanol and ethanol [52]. This technology is also suitable for treating a combination of microalgae and macroalgae for heavy metal bioremediation and bioenergy production [86]. The use of alcoholic solvents increased the bio-oil yield and converted the acids obtained in bio-oil to the corresponding methyl and ethyl esters. High-temperature liquefaction was used to improve the hydrolysis yield of Ulva sugars, which is already higher than other agricultural biomass [87]. This process generated less microbial inhibitors (HMF, 5-hydroxymethylfurfural) regarding other pre-treatments. After comparing different pre-treatments (organic solvents, alkaline solvents, liquid hot water and ionic liquids) to obtain an efficiency saccharification of Ulva, it appears that organic solvent and liquid hot water provide the highest glucan yield with $81 \%$ and $63 \%$, respectively [88]. The most efficient saccharification before ethanol production is reached with the liquid hot water treatment with a $98 \%$ yield.

\subsection{Microwave Assisted Hydrothermal Extraction}

This technology is based on the use of electromagnetic radiation with frequencies in the range from $300 \mathrm{MHz}$ to $300 \mathrm{GHz}$. This non-ionizing radiation generates heat by two mechanisms that are ionic conduction and dipole rotation, which usually occur simultaneously. Microwave is proposed for drying [89] and for the assisted hydrothermal extraction of sulphated polysaccharides. Microwave-assisted extraction using distilled water as solvent is used for the extraction of Ulvans [90]. This technique also offers operational and environmental advantages for the extraction of essential oils. Microwave-assisted hydro distillation was proposed to obtain essential oils with free-radical scavenging and antioxidant potential, as well as some components of medicinal importance to be used as a food additive and dietary supplement [91]. The transesterification of Ulva oils to biodiesel was obtained with significant yields in $1 \mathrm{~h}$ at $60^{\circ} \mathrm{C}$ with sodium hydroxide and at room temperature with Na metal [92]. The microwave assisted transesterification could be completed within 5 min, 
but the highly exothermic and uncontrollable reaction of sodium metal in microwave damages the equipment. A microwave-assisted direct Ulva liquefaction using sulfuric acid was used as a catalyst to produce bio-oil [93]. Microwave-assisted liquefaction of Ulva under atmospheric pressure using a $\mathrm{Fe}_{2} \mathrm{O}_{3}$-modified catalyst increased the bio-oil yield and facilitated the production of long-chain compounds with a decrease in the oxygen content in the bio-fuel [94]. Microwave irradiation showed higher production of sugars compared with external conduction heating. Microwave irradiation efficacy for hydrolysis was also demonstrated with the addition of polyoxometalate clusters to produce larger amounts of reducing sugars than hydrochloric and sulfuric acids and inducing a lower amount (less than $0.1 \%$ ) of furfural derivatives $[95,96]$. Phosphotungstic acid was found to be the most suitable agent and was recycled at least three times by diethyl ether extraction without changing its activity. Hydrothermal temperature until $140{ }^{\circ} \mathrm{C}$ was highly influential on the enzymatic Ulva hydrolysis and shortened the required reaction time [97].

\subsection{Ultrasound}

Ultrasound waves create compression and expansion when they go through a medium inducing cavitation. This phenomenon due to the production, growth and collapse of bubbles, which implode in the liquid near the solid surface of membranes, causes surface peeling, erosion and particle breakdown [98]. Intensification by ultrasound makes possible extraction due to a more effective mixing, and thermal and structural effects (fragmentation, erosion, sonocapillary, sonoporation, detexturation), as well as enhanced solute diffusion and washing. However, oxidation and degradation of compounds occurred as a result of solvent vapor, high pressures and temperature, which generate primary radicals susceptible of forming other radicals and molecules [99]. High power ultrasound can be an efficient tool for large scale applications because of improved equipment design and efficiencies of continuous operation. Ultra-sonication reduced the extraction time and solvent consumption, making possible a greater penetration of solvent into cellular materials and improving the release of cell contents into the bulk medium. In addition, this technique may also provide more economic and environmental as well as health and safety benefits [48]. The ultrasonic pre-treatment method improves extractions of oil with higher efficiency, reducing extraction time and increasing yields, with moderate costs and negligible toxicity. The ultrasonic pre-treatment method also reduces extraction time [48]. Solvent mixtures, i.e., diethyl ether and methylene chloride in n-hexane, can also favor high oil yields. Autoclave and ultrasound pre-treatments enhanced the oil extraction yield because they damage the Ulva membranes. Extraction of oil from Ulva biomass using the ultrasound pre-treatment method showed better results when compared with other methods, such as deep-freezing, lyophilization and microwave pre-treatment methods, which caused partial hydrolysis and pre-esterification of the oil. Using sonication in water (and subsequent ammonium sulphate-induced protein precipitation) provided the greatest protein yields, but the protein and fatty acids content was higher with the alkaline protein solubilization [87]. An optimized ultrasound-assisted extraction of crude Ulva sulphated polysaccharides showed radical scavenging, reducing power and a macrophage-stimulating capacity [100].

\subsection{Supercritical Fluid Extraction}

This technology is based on the utilization of solvents under conditions leading to the supercritical state, which presents physicochemical properties between those of the liquid and the gaseous state, facilitating the solubility and mass transfer. The preferred solvent is carbon dioxide, for its availability, cost, low toxicity and the possibility of using low temperatures. Carbon dioxide makes it possible to maintain thermos labile compounds and characteristics close to natural products. This has advantages, as the lack of solvent residues in the final product and the selective recovery of the target solutes in the supercritical extract would favor its potential use for food, pharmaceutical and cosmetic industries. Supercritical fluid extraction of Ulva was proposed to obtain carotenoids and phenolic compounds with antioxidant properties [101]. This technique provided a better quality for fatty acids, carotenoids 
and chlorophylls compared to conventional ethanol extraction. The presence of polyphenols due to this technique conferred antioxidant properties for cosmetic applications [102]. SC- $\mathrm{CO}_{2}$ extraction also provided efficient extraction of polyphenols [103]. Supercritical $\mathrm{CO}_{2}$ extraction made it possible to obtain extracts containing secondary metabolites with plant growth bio-stimulant properties. When applied by foliar feed on cress and seed maceration for wheat, the extracts enhanced chlorophyll and carotenoid content, root thickness and above-ground biomass.
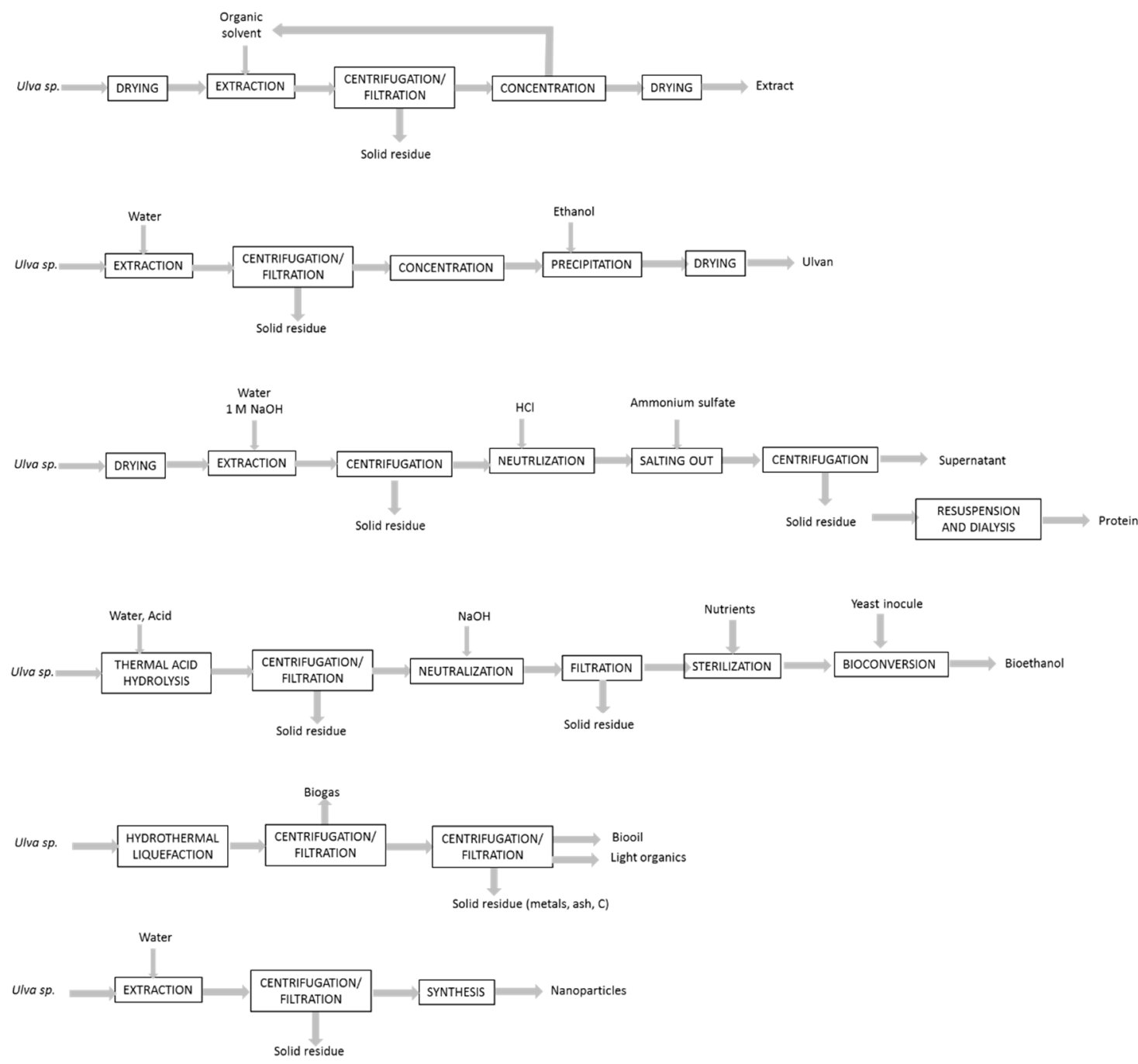

Figure 2. Examples of processes proposed to improve the extraction of Ulva components.

\subsection{Enzyme Extraction}

This technology has improved since the last decade. Although the Ulva proteins and polysaccharides are usually extracted with water or polar organic solvents, the presence of complex polymers, accessibility problems and the attack of polysaccharides with hydrolytic enzymes damage the cell wall and release intracellular material. To improve enzyme extraction efficiency, new procedures have been developed, such as acid extraction and combined enzymatic-chemical extraction, providing antioxidant properties to ulvan [104]. Enzyme-assisted extraction was applied for Ulva bioconversion to produce antiviral and antioxidant extracts [105]. Endoproteases, as well as the combined mixture of carbohydrase, increased the extraction yields as well as the sugar and protein contents in the extracts, which showed free radical scavenging properties. The use of an enzyme-assisted extraction using commercial proteases and carbohydrases improves the extraction efficiency compared to water extraction at $50^{\circ} \mathrm{C}$ [106]. This technique is less effective for polyphenol recovery, and increased from 
$0.41 \%$ to $0.99 \%$ in the dry weight ( $\mathrm{dw}$ ) hydrolysate, and it is promising for the extraction of Ulvans, which increased from $8.99 \%$ to $21.09 \%$ the dw hydrolysate. In addition, all hydrolysate fractions tested were non-toxic to human cells but were active against the Herpes simplex virus. Hydrolysis with cell wall enzymatic degradation offered different results depending on Ulva phenotypes [107]. The best results were obtained with the use of a polysaccharidase mixture ( $\beta$-glucanase, hemicellulase, cellulose).

Ulvan is found in cell-walls, particularly between the two cell layers constituting the thallus, and ulvan depolymerization gives high-value oligosaccharides or fermentable monosaccharides for the production of bio-active compounds and bioethanol [108]. However, most tested enzymes are those commercially available, and further studies of Ulvan depolymerizing enzymes, such as ulvan lyases, are needed $[109,110]$. The extraction with water at $90^{\circ} \mathrm{C}$, sterilization at $121^{\circ} \mathrm{C}$, homogenization and enzymatic hydrolysis made it possible to obtain extracts with antiradical and reducing properties [111].

Pulsed electric field treatment is based on the application of a high voltage (up to $80 \mathrm{kV} / \mathrm{cm}$ ) in short pulses at room temperature. This technique causes the formation of pores in the cell membranes of the biomass placed between two electrodes and is referred as electroporation or electro permeabilization. This phenomenon is due to the accumulation of opposite charges on cell membranes and their move under the influence of an electric field. Tissue disintegration caused by electroporation facilitates the release of intracellular compounds, enhancing the extraction yields such as with proteins [112]. Pulsed electric field treatment enhances dashing Ulva biomass using hydraulic pressing, providing a higher extraction of $\mathrm{K}, \mathrm{Mg}, \mathrm{Na}, \mathrm{P}$ and S compared to pressing alone. High-voltage pulsed electric field treatment was more efficient for cell-membrane permeabilization and protein extraction than osmotic shock [113]. The protein concentration in the final product increased because of the removal of protein compounds, and the extract had a higher antioxidant capacity. However, incubation with pectinase and pulsed electric field treatment was less efficient for the extraction of water-soluble proteins and carbohydrates from Ulva compared to shear homogenization. The need for deep investigation of algal proteins and protein extraction technology for health is important, since osmotic shock combined with pulsed electric fields and hydraulic pressure produced extracts containing food allergens, such as superoxide dismutase, aldolase and thioredoxin [111]. Table 1 summarizes some examples of application of different technologies for the extraction of Ulva components.

Table 1. Examples of treatments for extraction and production of valuable components from Ulva.

\begin{tabular}{|c|c|c|}
\hline Extraction and Pretreatment Stages of Ulva lactuca (U. l.) & Products & Ref. \\
\hline U. l. clathrata. Extraction $\left(0.2 \mathrm{~N} \mathrm{HCl}, 60^{\circ} \mathrm{C}, 2 \mathrm{~h}+0.1 \mathrm{M} \mathrm{NaOH}, 60^{\circ} \mathrm{C}, 2 \mathrm{~h}\right)$ & $\mathrm{U}, \operatorname{Pr}$ & [64] \\
\hline Supercritical (sc)- $\mathrm{CO}_{2}\left(50 \mathrm{MPa}, 40^{\circ} \mathrm{C}, 300-810 \mathrm{~min}\right)$ & $\mathrm{A}, \mathrm{Cy}, \mathrm{M}, \mathrm{Ph}$ & [106] \\
\hline $\begin{array}{l}\text { U. l. fasciata. Ultrasound pretreatment }\left(24 \mathrm{kHz}, 50{ }^{\circ} \mathrm{C}, 6 \mathrm{~min}\right)+ \\
\text { chloroform:methanol:hexane }\left(90^{\circ} \mathrm{C}, 3 \mathrm{~h}\right) \text { or sc }-\mathrm{CO}_{2}\left(200^{\circ} \mathrm{C}, 150 \mathrm{bar}, 2.14 \mathrm{~L} / \mathrm{h}\right)\end{array}$ & $\mathrm{O}$ & {$[56]$} \\
\hline $\begin{array}{c}\text { Acid }\left(1-3 \% \mathrm{H}_{2} \mathrm{SO}_{4}, 100-121^{\circ} \mathrm{C}, 0.3-1 \mathrm{~h}\right) \text { or alkaline }\left(\mathrm{NaOH}, 121^{\circ} \mathrm{C}, 20.3 \mathrm{~h}\right) \text { or } \\
\text { buffer }\left(\mathrm{pH} 4.8,120^{\circ} \mathrm{C}, 1 \mathrm{~h}\right) \text { or dry heat }\left(120^{\circ} \mathrm{C}, 1 \mathrm{~h}\right) \text { or liquid ammonia } \\
(2 \%, 0.25 \mathrm{~h})+\text { enzyme saccharification }+ \text { bioconversion }\end{array}$ & E & {$[114,115]$} \\
\hline Dichloromethane, 7 days, 3 stages; adsorption, transesterification & $\mathrm{BD}$ & [97] \\
\hline U. l. flexuosa. $\mathrm{Sc}-\mathrm{CO}_{2}$ extraction $\left(40^{\circ} \mathrm{C}, 30 \mathrm{MPa}, 11.4 \%\right)$ & Car, Chl & [104] \\
\hline U. l. intestinalis. Liquefaction (deionized water, LSR $5 ; 345^{\circ} \mathrm{C} ; 30 \mathrm{~K} / \mathrm{min}$ ) & $\mathrm{BO}$ & [44] \\
\hline US assisted extraction $\left(66^{\circ} \mathrm{C}, 40 \mathrm{~min}, \mathrm{LSR} 50, \mathrm{pH} 7.0\right)$ & $\mathrm{U}$ & [116] \\
\hline U. l. Aqueous pretreatment $\left(150^{\circ} \mathrm{C}\right)+$ enzyme extraction + bioconversion & $\operatorname{Pr}, A c, B, E$ & [81] \\
\hline $\begin{array}{l}\text { Water, thermal treatment }\left(60^{\circ} \mathrm{C}, 45 \mathrm{~min}\right) \text { or water }\left(\mathrm{pH} 2,95^{\circ} \mathrm{C}, 3 \mathrm{~h}\right) \text { or alkaline } \\
\text { extraction }\left(0.25 \mathrm{M} \mathrm{NaOH} ; 60^{\circ} \mathrm{C}, 1 \mathrm{~h}\right)+\text { anaerobic digestion }\end{array}$ & $\mathrm{S}, \mathrm{U}, \mathrm{Pr}, \mathrm{BG}$ & [59] \\
\hline Acid pretreatment $\left(\mathrm{H}_{2} \mathrm{SO}_{4}, \mathrm{pH} 2,150^{\circ} \mathrm{C}, 10 \mathrm{~min}\right)$; enzyme saccharification & Ac, B, E & [52] \\
\hline MA water extraction $\left(500 \mathrm{~W}, 70^{\circ} \mathrm{C}, 20 \mathrm{~min}\right)$ or acid extraction $\left(\mathrm{pH} 1.5,90^{\circ} \mathrm{C}\right)$ & $\mathrm{U}$ & {$[62,95]$} \\
\hline
\end{tabular}


Table 1. Cont.

\begin{tabular}{|c|c|c|}
\hline Extraction and Pretreatment Stages of Ulva lactuca (U. l.) & Products & Ref. \\
\hline Bioconversion & BG & [54] \\
\hline US water extraction or alkaline extraction or accelerated extraction & $\operatorname{Pr}$ & [87] \\
\hline $\begin{array}{l}\text { Incubation with water/heat treatment + lipid extraction + water extraction } \\
\qquad\left(90^{\circ} \mathrm{C}, 2 \mathrm{~h}\right)+\text { protein extraction }\left(1 \mathrm{~N} \mathrm{NaOH}, 80^{\circ} \mathrm{C}\right)\end{array}$ & $\mathrm{S}, \mathrm{O}, \mathrm{U}, \mathrm{Pr}, \mathrm{C}$ & [83] \\
\hline US pretreatment (LSR $\left.3,24 \mathrm{kHz}, 50^{\circ} \mathrm{C}, 5 \mathrm{~min}\right)$; solvent extraction & $\mathrm{O}$ & [48] \\
\hline $\begin{array}{c}\left.\text { OS }\left(30^{\circ} \mathrm{C}, 24 \mathrm{~h}\right) \text { or enzyme ( } \mathrm{pH} 4,25^{\circ} \mathrm{C}, 0.5 \% \text { pectinase, } 4 \mathrm{~h}\right) \text { or PEF }(7.5 \mathrm{kV} / \mathrm{cm} \text {, } \\
0.05 \mathrm{~ms} \text { pulses, } 6.6 \mathrm{kWh} / \mathrm{kg} \text { prot })\end{array}$ & $\operatorname{Pr}, \mathrm{U}$ & [113] \\
\hline Liquefaction (deionized water, LSR $5 ; 345^{\circ} \mathrm{C} ; 30 \mathrm{~K} / \mathrm{min}$ ) & $\mathrm{BO}$ & [44] \\
\hline $\begin{array}{l}\text { Water or buffer or PEF (75 pulses, } 2.9 \mathrm{kV} / \mathrm{cm}, 5.7 \mu \mathrm{s}, 0.5 \mathrm{~Hz}) \text {, pressing } \\
\qquad\left(5 \mathrm{~min}, 45 \mathrm{daN} / \mathrm{cm}^{2}\right)\end{array}$ & $\mathrm{U}, \operatorname{Pr}$ & [111] \\
\hline PEF (247 kJ/kg fw, 50 pulses, 50 kV, 70.3 mm electrode gap) & $\operatorname{Pr}$ & [115] \\
\hline EA aqueous extraction $\left(0.5 \%, 50^{\circ} \mathrm{C}, 5 \mathrm{~h}\right)$ & Ph, Pr, U & [100] \\
\hline U. l. linza. Extraction ( $\left.\mathrm{pH} 1.5-2,60^{\circ} \mathrm{C}, 2 \mathrm{~h}\right)$; re-extraction $\left(\mathrm{pH}=2,60^{\circ} \mathrm{C}, 1 \mathrm{~h}\right)$ & $\mathrm{U}$ & [30] \\
\hline U. l. meridionalis and U. l. ohnoi. MA hydrothermal extraction $\left(4+10 \mathrm{~min}, 160^{\circ} \mathrm{C}\right)$ & $\mathrm{U}$ & [94] \\
\hline U. pertusa. Liquefaction $\left(150^{\circ} \mathrm{C}, 15 \mathrm{MPa}, 15 \mathrm{~min}\right)$; enzyme saccharification & E & [91] \\
\hline U. l. prolifera. MA liquefaction $\left(6 \% \mathrm{H}_{2} \mathrm{SO}_{4}, 600 \mathrm{~W}, 30 \mathrm{~min}, 180^{\circ} \mathrm{C}\right)$ & $\mathrm{BO}$ & [98] \\
\hline MA liquefaction (ethylene glycol, $4.93 \% \mathrm{H}_{2} \mathrm{SO}_{4}$ ), $600 \mathrm{~W}, 30 \mathrm{~min}, 165^{\circ} \mathrm{C}$ & $\mathrm{BO}$ & [21] \\
\hline U. l. rigida. Aqueous extraction $\left(100^{\circ} \mathrm{C}, 1 \mathrm{~h}\right)$ & $\mathrm{Ph}$ & [38] \\
\hline Aqueous extraction $\left(125^{\circ} \mathrm{C}, 1.5 \mathrm{bar}, 1 \mathrm{~h}\right)+\mathrm{SSF}$ & U, Pr, E & [75] \\
\hline EA extraction (pepsin + bromelain, $37^{\circ} \mathrm{C}, \mathrm{pH} 2.0,20+20 \mathrm{~h}$ ) & $\operatorname{Pr}$ & [28] \\
\hline Acid hydrolysis $\left(2-4 \%\right.$ acid, $\left.121^{\circ} \mathrm{C}, 30-60 \mathrm{~min}\right)$ & E & {$[50,51]$} \\
\hline
\end{tabular}

\section{Conclusions and Future Trends}

This review shows that many different approaches have been developed to valorize Ulva. The potential valorization of Ulva to produce bioethanol was particularly studied. Ethanol is actually mainly commercialized as an adjuvant (up to $15 \%$ ) to diesel (or gazole) fuel that does not require an adaptation of the diesel engine. It could be a tool to fight air pollution from vehicles because of its biodegradable nature, since ethanol contains $35 \%$ oxygen and adding oxygen to diesel results in more complete fuel combustion, reducing harmful tailpipe emissions [117]. Vehicles with an unleaded gasoline engine can be modified to use only ethanol, but this operation increases $\mathrm{CO}_{2}$ emission. The problem is that bioethanol can also be obtained from sugar cane or other agricultural productions at a much lower cost compared to Ulva biorefinery, regardless of the process. Furthermore, the use of diesel or other organic fuels should decrease to reduce $\mathrm{CO}_{2}$ emission. It is therefore probable that efforts to have a competitive source of bioethanol from Ulva could turn out to be useless in the future when electricity and hydrogen will replace organic fuels.

The valorization of Ulva wastes will also remain difficult for pharmaceutical drugs, cosmetics or food due to contaminants that have to be eliminated. New compounds useful for the pharmaceutical industry that could be isolated from Ulva will have to be chemically produced to be commercialized. It is important to note that screenings with biological tests should be preferentially carried out on the Ulva protein fraction, since it is easier to have authorization for a clinical trial with injectable synthetic proteins [118]. Furthermore, it could be possible to transform the biomass from Ulva with enzymes to obtain new products that may have interest for the food industry, as it possible now from vineyard biomass [119]. Plant glycosyltransferases are able to modify a range of small molecules, including 
terpenoids, phenolics and alkaloids found in Ulva. Finally, it would be possible to introduce into the Ulva genome genes from plants such as strawberry [119].

Ulva blooms will remain a source of troubles that could grow with increased global warming. However, there is a natural law called "kill the winner" that may interrupt this Ulva success story. When there is proliferation of a species, a predator of this species appears to control this proliferation. Among the most powerful natural predators, the biggest is not necessarily the most efficient. Viruses have demonstrated this, even for the human since the HIV has been found to be our most dangerous predator [120]. What is interesting with viruses is their specificity regarding their target, which is not the case for other predators such as humans, who can control or eradicate many different species. The apparition of a virus specific of Ulva may be a consequence of the high concentration of viruses in the Mediterranean seas. Viruses are the most abundant biological entities in sea waters that can be found even in the bathypelagic (1000 to $2000 \mathrm{~m}$ ) zone, and the Mediterranean seas appear to have the highest concentration, mainly in the epipelagic $(5 \mathrm{~m})$ zone [121]. Prokaryotes and unicellular algae appear to be the main viral hosts, but only $9 \%$ of sequences obtained from the viral fraction had an identifiable viral origin, and no research has been carried out with sequences specific to giant viruses [121].

Finally, the use of bioinformatic tools based on a multi-omic modelling work could be useful to improve the Ulva valorization process, to predict Ulva blooms and to evaluate the ecological impact resulting from the introduction of a virus in a different ecological system. Compared to approaches applying machine learning on omic data directly, a multi-view approach merging experimentally and model-generated omic data can include key mechanistic information in an otherwise biology-agnostic machine learning process [122].

Author Contributions: Conceptualization, H.D. and E.P.L.; formal analysis, H.D. and E.P.L.; resources, H.D. and E.P.L.; writing—original draft preparation, H.D. and E.P.L.; writing-review and editing, H.D. and E.P.L.; project administration, E.P.L.; funding acquisition, H.D. and E.P.L.

Funding: This research was funded by Xunta de Galicia (Centro singular de investigación de Galicia, ED431G/02 and Grupos de referencia competitiva EDC431C 2018/47), Aix Marseille University and CNRS.

Acknowledgments: E.P.L. thanks Gerard Pepe for its help for the study of Ulva blooms in the Mediterranean seas. E.P.L. thanks Fabrice Roth from Prefecture de Bretagne, Sylvain Ballu from Cente d'Evaluation et de Valorisation des Algues and CRESEB from Conseil Régional de Bretagne for fruitful discussions. E.P.L. thanks Ian McBitter for reviewing the manuscript.

Conflicts of Interest: The authors declare no conflict of interest.

\section{References}

1. Wichard, T.; Charrier, B.; Mineur, F.; Bothwell, J.H.; Clerck, O.D.; Coates, J.C. The green seaweed Ulva: A model system to study morphogenesis. Front. Plant Sci. 2015, 6, 72-82. [CrossRef] [PubMed]

2. Chevassus-au-Louis, B.; Andral, B.; Femenias, A.; Buvier, M. Bilan des Connaissances scientifiques sur Les Causes de Prolifération de Macroalgues Vertes; Rapport Pour Le Gouvernement Français 2012. Report No.: CGEDD 007942-01 et CGAAER 11128; Conseil Général de L'environnement et du Développement Durable: Paris, France, 2012. (In French)

3. Pillard, S. Mise au Point sur Les Algues Vertes: Risques Environnementaux et Valorisations en 2016; Sciences Pharmaceutiques 2016, Dumas-01393938; Universite de Picardie Jules Verne: Amiens, France, 2016. (In French)

4. Rybak, A. Species of Ulva (Ulvophyceae, Chlorophyta) as indicators of salinity. Ecol. Indic. 2018, 85, $253-261$. [CrossRef]

5. Kraan, S. Pigments and minor compounds in algae. In Functional Ingredients from Algae for Foods and Nutraceuticals; Domínguez, H., Ed.; Woodhead Publishing: Cambridge, UK, 2013; pp. 205-251.

6. Robin, A.; Sack, M.; Israel, A.; Frey, W.; Müller, G.; Golberg, A. Deashing macroalgae biomass by pulsed electric field treatment. Bioresour. Technol. 2018, 255, 131-139. [CrossRef] [PubMed]

7. Pérez, M.J.; Falqué, E.; Domínguez, H. Antimicrobial action of compounds from marine seaweed. Mar. Drugs 2016, 14, 52. [CrossRef] [PubMed] 
8. Neto, R.T.; Marçal, C.; Queirós, A.S.; Abreu, H.; Silva, A.M.S.; Cardoso, S.M. Screening of Ulva rigida, Gracilaria sp.; Fucus vesiculosus and Saccharina latissima as functional ingredients. Int. J. Mol. Sci. 2018, 19, 2987. [CrossRef] [PubMed]

9. Smetacek, V.; Zingone, A. Green and golden seaweed tides on the rise. Nature 2013, 504, 84-88. [CrossRef] [PubMed]

10. Popa, E.G.; Reis, R.L.; Gomes, M.E. Seaweed polysaccharide-based hydrogels used for the regeneration of articular cartilage. Crit. Rev. Biotechnol 2014, 3, 410-424. [CrossRef]

11. Morelli, A.; Betti, M.; Puppi, D.; Chiellini, F. Design, preparation and characterization of Ulvan based thermosensitive hydrogels. Carbohydr. Polym. 2016, 136, 1108-1117. [CrossRef]

12. Lordan, S.; Ross, R.P.; Stanton, C. Marine bioactives as functional food ingredients: Potential to reduce the incidence of chronic diseases. Mar. Drugs 2011, 9, 1056-1100. [CrossRef]

13. Hayden, H.S.; Blomster, J.; Maggs, C.A.; Silva, P.C.; Stanhope, M.J.; Waaland, J.R. Linnaeus was right all along: Ulva and Enteromorpha are not distinct genera. Eur. J. Phycol. 2003, 38, 277-294. [CrossRef]

14. Kirkendale, L.; Saunders, G.W.; Winberg, P. A Molecular survey of Ulva (Chlorophyta) in temperate Australia reveals enhanced levels of cosmopolitanism. J. Phycol. 2012, 49, 69-81. [CrossRef] [PubMed]

15. Letts, E.A.; Richards, E.H. Report on green seaweeds and especially Ulva latissima in relation to the pollution of the waters in which they occur. In Royal Commission on Sewage Disposal; 7th Report, Appendix III, Section II; HMSO: London, UK, 1911.

16. Schiffner, V.; Vatova, A. The Algae of the Lagoon: Chlorophyceae, Phaeophyceae, Rhodophyceae, Myxophyceae; Minio, M., Ed.; The Lagoon of Venice: Venezia, Italy, 1938; Volume 3, p. 250. (In Italian)

17. Curiel, D.; Rismondo, A.; Bellemo, G.; Marzocchi, M. Macroalgal biomass and species variations in the lagoon of Venice (Northern Adriatic Sea, Italy): 1981-1998. Sci. Mar. 2004, 68, 57-67. [CrossRef]

18. Villares, R.; Puente, X.; Carballeira, A. Nitrogen and phosphorus in Ulva sp. in the Galician Rias Bajas (northwest Spain): Seasonal fluctuations and influence on growth. Bol. Inst. Esp. Oceanogr. 1999, 15, 337-341.

19. Yabe, T.; Ishii, Y.; Amano, Y.; Koga, T.; Hayashi, S.; Nohara, S.; Tatsumoto, H. Green tide formed by free-floating Ulva spp. at Yatsu tidal flat, Japan. Limnology 2009, 10, 239-245. [CrossRef]

20. Charlier, R.H.; Morand, P.; Finkl, C.W. How Brittany and Florida coasts cope with green tides. Int. J. Environ. Stud. 2008, 65, 191-208. [CrossRef]

21. Li, J.-Y.; Yang, F.; Jin, L.; Wang, Q.; Yin, J.; He, P.; Chen, Y. Safety and quality of the green tide algal species Ulva prolifera for option of human consumption: A nutrition and contamination study. Chemosphere 2018, 210, 1021-1028. [CrossRef]

22. Moniruzzaman, M.; Gann, E.R.; Wilhelm, S.W. Infection by a giant virus (AaV) induces widespread physiological reprogramming in Aureococcus anophagefferens CCMP1984, a Harmful Bloom Algae. Front. Microbiol. 2018, 9, 752-758. [CrossRef]

23. Schvarcz, C.R.; Steward, G.F. A giant virus infecting green algae encodes key fermentation genes. Virology 2018, 518, 423-433. [CrossRef]

24. La Scola, B.; Audic, S.; Robert, C.; Jungang, L.; de Lamballerie, X.; Drancourt, M.; Birtles, R.; Claverie, J.M.; Raoult, D. A giant virus in amoebae. Science 2003, 299, 2033-2038. [CrossRef]

25. Abergel, C.; Legendre, M.; Claverie, J.M. The rapidly expanding universe of giantviruses: Mimivirus, Pandoravirus, Pithovirus and Mollivirus. FEMS Microbiol. Rev. 2015, 39, 779-796. [CrossRef]

26. Cardoso, S.M.; Carvalho, L.G.; Silva, P.J.; Rodrigues, M.S.; Pereira, O.R.; Pereira, L. Bioproducts from seaweeds: A review with special focus on the Iberian Peninsula. Curr. Org. Chem. 2014, 18, 896-917. [CrossRef]

27. Kazir, M.; Abuhassira, Y.; Robin, A.; Nahor, O.; Luo, J.; Israel, A.; Golberg, A.; Livney, Y.D. Extraction of proteins from two marine macroalgae, Ulva sp. and Gracilaria sp.; for food application, and evaluating digestibility, amino acid composition and antioxidant properties of the protein concentrates. Food Hydrocoll. 2019, 87, 194-203. [CrossRef]

28. Paiva, L.; Lima, E.; Neto, A.I.; Baptista, J. Isolation and characterization of angiotensin I-converting enzyme (ACE) inhibitory peptides from Ulva rigida C. Agardh protein hydrolysate. J. Funct. Foods 2016, 26, 65-76. [CrossRef] 
29. Cian, R.E.; Hernández-Chirlaque, C.; Gámez-Belmonte, R.; Drago, S.R.; Sánchez de Medina, F.; Martínez-Augustin, O. Green alga Ulva sp. hydrolysates and their peptide fractions regulate cytokine production in splenic macrophages and lymphocytes involving the TLR4-NFkB/MAPK pathways. Mar. Drugs 2018, 16, 235. [CrossRef] [PubMed]

30. Sari-Chmayssem, N.; Taha, S.; Mawlawi, H.; Guégan, J.-P.; Jeftić, J.; Benvegnu, T. Extracted Ulvans from green algae Ulva linza of Lebanese origin and amphiphilic derivatives: Evaluation of their physico-chemical and rheological properties. J. Appl. Phycol. 2018, 3, 1-16. [CrossRef]

31. Violle, N.; Rozan, P.; Demais, H.; Nyvall Collen, P.; Bisson, J.-F. Evaluation of the antidepressant- and anxiolytic-like effects of a hydrophilic extract from the green seaweed Ulva sp. in rats. Nutr. Neurosci. 2018, 21, 248-256. [CrossRef] [PubMed]

32. Cesário, M.T.; da Fonseca, M.M.R.; Marques, M.M.; de Almeida, M.C.M.D. Marine algal carbohydrates as carbon sources for the production of biochemicals and biomaterials. Biotechnol. Adv. 2018, 36, 798-817. [CrossRef]

33. Dumbrava, A.; Berger, D.; Matei, C.; Radu, M.D.; Gheorghe, E. Characterization and applications of a new composite material obtained by green synthesis, through deposition of zinc oxide onto calcium carbonate precipitated in green seaweeds extract. Ceram. Int. 2018, 44, 4931-4936. [CrossRef]

34. McCauley, J.I.; Winberg, P.C.; Meyer, B.J.; Skropeta, D. Effects of nutrients and processing on the nutritionally important metabolites of Ulva sp. (Chlorophyta). Algal Res. 2018, 35, 586-594. [CrossRef]

35. Zhang, C.; Lu, J.; Wu, J.; Luo, Y. Phycoremediation of coastal waters contaminated with bisphenol A by green tidal algae Ulva prolifera. Sci. Total Environ. 2019, 661, 55-62. [CrossRef]

36. Fleurence, J.; Le Coeur, C.; Mabeau, S.; Maurice, M.; Landrein, A. Comparison of different extractive procedures for proteins from the edible seaweeds Ulva rigida and Ulva rotundata. J. Appl. Phycol. 1995, 7,577-582. [CrossRef]

37. Laramore, S.; Baptiste, R.; Wills, P.S.; Hanisak, M.D. Utilization of IMTA-produced Ulva lactuca to supplement or partially replace pelleted diets in shrimp (Litopenaeus vannamei) reared in a clear water production system. J. Appl. Phycol. 2018, 2, 3603-3610. [CrossRef]

38. Cruz-Suárez, L.E.; León, A.; Peña-Rodríguez, A.; Rodríguez-Peña, G.; Moll, B.; Ricque-Marie, D. Shrimp/Ulva co-culture: A sustainable alternative to diminish the need for artificial feed and improve shrimp quality. Aquaculture 2010, 301, 64-68. [CrossRef]

39. Mansori, M.; Chernane, H.; Latique, S.; Benaliat, A.; Hsissou, D.; El Kaoua, M. Seaweed extract effect on water deficit and antioxidative mechanisms in bean plants (Phaseolus vulgaris L.). J. Appl. Phycol. 2015, 27, 1689-1698. [CrossRef]

40. Mansori, M.; Chernane, H.; Latique, S.; Benaliat, A.; Hsissou, D.; El Kaoua, M. Effect of seaweed extract (Ulva rigida) on the water deficit tolerance of Salvia officinalis L. J. Appl. Phycol. 2016, 28, 1363-1370. [CrossRef]

41. Balboa, E.M.; Soto, M.L.; Nogueira, D.R.; González-López, N.; Conde, E.; Moure, A.; Vinardell, M.P.; Mitjans, M.; Domínguez, H. Potential of antioxidant extracts produced by aqueous processing of renewable resources for the formulation of cosmetics. Ind. Crop Prod. 2014, 58, 104-110. [CrossRef]

42. González-Ballesteros, N.; Rodríguez-Argüelles, M.C.; Prado-López, S.; Lastra, M.; Grimaldi, M.; Cavazza, A.; Nasi, L.; Salviati, G.; Bigi, F. Macroalgae to nanoparticles: Study of Ulva lactuca L. role in biosynthesis of gold and silver nanoparticles and of their cytotoxicity on colon cancer cell lines. Mater. Sci. Eng. C 2019, 97, 498-509. [CrossRef]

43. Bruhn, A.; Dahl, J.; Nielsen, H.B.; Nikolaisen, L.; Rasmussen, M.B.; Markager, S.; Olesen, B.; Arias, C.; Jensen, P.D. Bioenergy potential of Ulva lactuca: Biomass yield, methane production and combustion. Bioresour. Technol. 2011, 102, 2595-2604. [CrossRef]

44. Mata, L.; Magnusson, M.; Paul, N.A.; de Nys, R. The intensive land-based production of the green seaweeds Derbesia tenuissima and Ulva ohnoi: Biomass and bioproducts. J. Appl. Phycol. 2016, 28, 365-375. [CrossRef]

45. Chemodanov, A.; Jinjikhashvily, G.; Habiby, O.; Liberzon, A.; Israel, A.; Yakhini, Z.; Golberg, A. Net primary productivity, biofuel production and $\mathrm{CO}_{2}$ emissions reduction potential of Ulva sp. (Chlorophyta) biomass in a coastal area of the Eastern Mediterranean. Energy Convers. Manag. 2018, 166, 772-779. [CrossRef]

46. Raikova, S.; Le, C.D.; Beacham, T.A.; Jenkins, R.W.; Allen, M.J.; Chuck, C.J. Towards a marine biorefinery through the hydrothermal liquefaction of macroalgae native to the United Kingdom. Biomass Bioenergy 2017, 107, 244-253. [CrossRef] 
47. Soliman, R.M.; Younis, S.A.; El-Gendy, N.S.; Mostafa, S.S.M.; El-Temtamy, S.A.; Hashim, A.I. Batch bioethanol production via the biological and chemical saccharification of some Egyptian marine macroalgae. J. Appl. Microbiol. 2018, 125, 422-440. [CrossRef] [PubMed]

48. Saqib, A.; Tabbssum, M.R.; Rashid, U.; Ibrahim, M.; Gill, S.S.; Mehmood, M.A. Marine macroalgae Ulva: A potential feed-stock for bioethanol and biogas production. Asian J. Agric. Biol. 2013, 3, 155-163.

49. Suganya, T.; Renganathan, S. Optimization and kinetic studies on algal oil extraction from marine macroalgae Ulva lactuca. Bioresour. Technol. 2012, 107, 319-326. [CrossRef] [PubMed]

50. Tabassum, M.R.; Xia, A.; Murphy, J.D. Potential of seaweed as a feedstock for renewable gaseous fuel production in Ireland. Renew. Sustain. Energy Rev. 2017, 68, 136-146. [CrossRef]

51. Jiang, R.; Ingle, K.N.; Golberg, A. Macroalgae (seaweed) for liquid transportation biofuel production: What is next? Algal Res. 2016, 14, 48-57. [CrossRef]

52. El Harchi, M.; Fakihi Kachkach, F.Z.; El Mtili, N. Optimization of thermal acid hydrolysis for bioethanol production from Ulva rigida with yeast Pachysolen tannophilus. S. Afr. J. Bot. 2018, 115, 161-169. [CrossRef]

53. Van der Wal, H.; Sperber, B.L.; Houweling-Tan, B.; Bakker, R.R.; Brandenburg, W.; López-Contreras, A.M. Production of acetone, butanol, and ethanol from biomass of the green seaweed Ulva lactuca. Bioresour. Technol. 2013, 128, 431-437. [CrossRef]

54. Karray, R.; Hamza, M.; Sayadi, S. Evaluation of ultrasonic, acid, thermo-alkaline and enzymatic pre-treatment on anaerobic digestion of Ulva rigida for biogas production. Bioresour. Technol. 2015, 187, 205-213. [CrossRef]

55. Koçer, A.T.; Özçimen, D. Investigation of the biogas production potential from algal wastes. Waste Manag. Res. 2018, 36, 1100-1105. [CrossRef]

56. Ganesh Saratale, R.; Kumar, G.; Banu, R.; Xia, A.; Periyasamy, S.; Dattatraya Saratale, G. A critical review on anaerobic digestion of microalgae and macroalgae and co-digestion of biomass for enhanced methane generation. Bioresour. Technol. 2018, 262, 319-332. [CrossRef] [PubMed]

57. Park, J.-I.; Lee, J.; Sim, S.J.; Lee, J.-H. Production of hydrogen from marine macro-algae biomass using anaerobic sewage sludge microflora. Biotechnol. Bioprocess Eng. 2009, 14, 307-315. [CrossRef]

58. Wijffels, R.H.; Barbosa, M.J.; Eppink, M.H.M. Microalgae for the production of bulk chemicals and biofuels. Biofuels Bioprod. Biorefin. 2010, 4, 287-295. [CrossRef]

59. Mhatre, A.; Gore, S.; Mhatre, A.; Trivedi, N.; Sharma, M.; Pandit, R.; Anil, A.; Lali, A. Effect of multiple product extractions on bio-methane potential of marine macrophytic green alga Ulva lactuca. Renew. Energy 2018, 132, 742-751. [CrossRef]

60. Wijesekara, I.; Lang, M.; Marty, C.; Gemin, M.-P.; Boulho, R.; Douzenel, P.; Wickramasinghe, I.; Bedoux, G.; Bourgougnon, N. Different extraction procedures and analysis of protein from Ulva sp. in Brittany. J. Appl. Phycol. 2017, 29, 2503-2511. [CrossRef]

61. Yaich, H.; Amira, A.B.; Abbes, F.; Bouaziz, M.; Besbes, S.; Richel, A.; Blecker, C.; Attia, H.; Garna, H. Effect of extraction procedures on structural, thermal and antioxidant properties of Ulvan from Ulva lactuca collected in Monastir coast. Int. J. Biol. Macromol. 2017, 105, 1430-1439. [CrossRef] [PubMed]

62. Tran, T.T.V.; Truong, H.B.; Tran, N.H.V.; Quach, T.M.T.; Nguyen, T.N.; Bui, M.L.; Yuguchi, Y.; Thanh, T.T.T. Structure, conformation in aqueous solution and antimicrobial activity of Ulvan extracted from green seaweed Ulva reticulata. Nat. Prod. Res. 2018, 32, 2291-2296. [CrossRef]

63. Hernández-Garibay, E.; Zertuche-González, J.A.; Pacheco-Ruíz, I. Isolation and chemical characterization of algal polysaccharides from the green seaweed Ulva clathrata (Roth) C. Agardh. J. Appl. Phycol. 2011, 23, 537-542. [CrossRef]

64. Yuan, Y.; Xu, X.; Jing, C.; Zou, P.; Zhang, C.; Li, Y. Microwave assisted hydrothermal extraction of polysaccharides from Ulva prolifera: Functional properties and bioactivities. Carbohydr. Polym. 2018, 181, 902-910. [CrossRef]

65. Kanno, K.; Fujita, Y.; Honda, S.; Takahashi, S.; Kato, S. Urethane foam of sulfated polysaccharide Ulvan derived from green-tide-forming chlorophyta: Synthesis and application in the removal of heavy metal ions from aqueous solutions. Polym. J. 2014, 46, 813-818. [CrossRef]

66. Kajiwara, T.; Matsui, K.; Akakabe, Y.; Murakawa, T.; Arai, C. Antimicrobial browning-inhibitory effect of flavor compounds in seaweeds. J. Appl. Phycol. 2006, 18, 413-422. [CrossRef]

67. De Lima, R.L.; Pires-Cavalcante, K.M.S.; de Alencar, D.B.; Viana, F.A.; Sampaio, A.H.; Saker-Sampaio, S. In vitro evaluation of antioxidant activity of methanolic extracts obtained from seaweeds endemic to the coast of Ceará, Brazil. Acta Sci. Technol. 2016, 38, 247-255. [CrossRef] 
68. Kellogg, J.; Lila, M.A. Chemical and in vitro assessment of Alaskan coastal vegetation antioxidant capacity. J. Agric. Food Chem. 2013, 61, 11025-11032. [CrossRef] [PubMed]

69. Raja, R.; Hemaiswarya, S.; Arunkumar, K.; Carvalho, I.S. Antioxidant activity and lipid profile of three seaweeds of Faro, Portugal. Rev. Bras. Bot. 2016, 39, 9-17. [CrossRef]

70. Cho, M.; Kang, I.-J.; Won, M.-H.; Lee, H.-S.; You, S. The antioxidant properties of ethanol extracts and their solvent-partitioned fractions from various green seaweeds. J. Med. Food 2010, 13, 1232-1239. [CrossRef]

71. Goh, C.S.; Lee, K.T. A visionary and conceptual macroalgae-based third-generation bioethanol (TGB) biorefinery in Sabah, Malaysia as an underlay for renewable and sustainable development. Renew. Sustain. Energy Rev. 2010, 14, 842-848. [CrossRef]

72. Golberg, A.; Vitkin, E.; Linshiz, G.; Khan, S.A.; Hillson, N.J.; Yakhini, Z.; Yarmush, M.L. Proposed design of distributed macroalgal biorefineries: Thermodynamics, bioconversion technology, and sustainability implications for developing economies. Biofuels Bioprod. Biorefin. 2014, 8, 67-82. [CrossRef]

73. Robin, A.; Chavel, P.; Chemodanov, A.; Israel, A.; Golberg, A. Diversity of monosaccharides in marine macroalgae from the Eastern Mediterranean Sea. Algal Res. 2017, 28, 118-127. [CrossRef]

74. Pezoa-Conte, R.; Leyton, A.; Baccini, A.; Ravanal, M.C.; Mäki-Arvela, P.; Grénman, H.; Xu, C.; Willför, S.; Lienqueo, M.E.; Mikkola, J.-P. Aqueous extraction of the sulfated polysaccharide Ulvan from the green alga Ulva rigida-Kinetics and modeling. Bioenergy Res. 2017, 10, 915-928. [CrossRef]

75. Chiesa, S.; Gnansounou, E. Protein extraction from biomass in a bioethanol refinery-Possible dietary applications: Use as animal feed and potential extension to human consumption. Bioresour. Technol. 2011, 102, 427-436. [CrossRef]

76. Ge, H.; Ni, Q.; Chen, Z.; Li, J.; Zhao, F. Effects of short period feeding polysaccharides from marine macroalga, Ulva prolifera on growth and resistance of Litopenaeus vannamei against Vibrio parahaemolyticus infection. J. Appl. Phycol. 2018, 10, 1663-1669. [CrossRef]

77. Bikker, P.; van Krimpen, M.M.; van Wikselaar, P.; Houweling-Tan, B.; Scaccia, N.; van Hal, J.W.; Huijgen, W.J.J.; Cone, J.W.; López-Contreras, A.M. Biorefinery of the green seaweed Ulva lactuca to produce animal feed, chemicals and biofuels. J. Appl. Phycol. 2016, 28, 3511-3525. [CrossRef] [PubMed]

78. Gajaria, T.K.; Suthar, P.; Baghel, R.S.; Balar, N.B.; Sharnagat, P.; Mantri, V.A.; Reddy, C.R.K. Integration of protein extraction with a stream of byproducts from marine macroalgae: A model forms the basis for marine bioeconomy. Bioresour. Technol. 2017, 243, 867-873. [CrossRef] [PubMed]

79. Magnusson, M.; Carl, C.; Mata, L.; de Nys, R.; Paul, N.A. Seaweed salt from Ulva: A novel first step in a cascading biorefinery model. Algal Res. 2016, 16, 308-316. [CrossRef]

80. Schiener, P.; Atack, T.; Wareing, R.A.; Kelly, M.S.; Hughes, A.D. The by-products from marine biofuels as a feed source for the aquaculture industry: A novel example of the biorefinery approach. Biomass Convers. Biorefin. 2016, 6, 281-287. [CrossRef]

81. Raikova, S.; Olsson, J.; Mayers, J.J.; Nylund, G.M.; Albers, E.; Chuck, C.J. Effect of geographical location on the variation in products formed from the hydrothermal liquefaction of Ulva intestinalis. Energy Fuels 2018, 10, 1021-1028. [CrossRef]

82. Díaz-Reinoso, B.; González-Muñoz, M.J.; Domínguez, H. Introduction. In Water Extraction of Bioactive Compounds; Domínguez, H., González-Muñoz, M.J., Eds.; Elsevier: Kidlington, UK, 2017.

83. Harrysson, H.; Hayes, M.; Eimer, F.; Carlsson, N.-G.; Toth, G.B.; Undeland, I. Production of protein extracts from Swedish red, green, and brown seaweeds, Porphyra umbilicalis Kützing, Ulva lactuca Linnaeus, and Saccharina latissima (Linnaeus) J. V. Lamouroux using three different methods. J. Appl. Phycol. 2018, 10, 1-16. [CrossRef]

84. Boisvert, C.; Beaulieu, L.; Bonnet, C.; Pelletier, E. Assessment of the antioxidant and antibacterial activities of three species of edible seaweeds. J. Food Biochem. 2015, 39, 377-387. [CrossRef]

85. Singh, R.; Bhaskar, T.; Balagurumurthy, B. Effect of solvent on the hydrothermal liquefaction of macroalgae Ulva fasciata. Process Saf. Environ. Prot. 2015, 93, 154-160. [CrossRef]

86. Su, D.; Li, S.; Zhao, F.; Cao, Y. Drying dynamics of Ulva prolifera with the heat pump microwave method. Int. J. Simul. Syst. Sci. Technol. 2016, 17,1-7.

87. Piccini, M.; Raikova, S.; Allen, M.J.; Chuck, C.J. A synergistic use of microalgae and macroalgae for heavy metal bioremediation and bioenergy production through hydrothermal liquefaction. Sustain. Energy Fuels 2019, 3, 292-301. [CrossRef] 
88. Choi, W.Y.; Han, J.G.; Lee, C.G.; Song, C.H.; Kim, J.S.; Seo, Y.C.; Lee, S.E.; Jung, K.H.; Kang, D.H.; Heo, S.J.; et al. Bioethanol production from Ulva pertusa Kjellman by high-temperature liquefaction. Chem. Biochem. Eng. Q. 2012, 26, 15-21.

89. Jmel, M.A.; Anders, N.; Yahmed, N.B.; Schmitz, C.; Marzouki, M.N.; Spiess, A.; Smaali, I. Variations in physicochemical properties and bioconversion efficiency of Ulva lactuca polysaccharides after different biomass pretreatment techniques. Appl. Biochem. Biotechnol. 2018, 184, 777-793. [CrossRef] [PubMed]

90. Tsubaki, S.; Oono, K.; Hiraoka, M.; Onda, A.; Mitani, T. Microwave-assisted hydrothermal extraction of sulfated polysaccharides from Ulva spp. and Monostroma latissimum. Food Chem. 2016, 210, 311-316. [CrossRef]

91. He, J.; Xu, Y.; Chen, H.; Sun, P. Extraction, structural characterization, and potential antioxidant activity of the polysaccharides from four seaweeds. Int. J. Mol. Sci. 2016, 17, 1988. [CrossRef] [PubMed]

92. Patra, J.K.; Kim, S.H.; Baek, K.-H. Antioxidant and free radical-scavenging potential of essential oil from Enteromorpha linza L. prepared by microwave-assisted hydrodistillation. J. Food Biochem. 2015, 39, 80-90. [CrossRef]

93. Khan, A.M.; Fatima, N. Synthesis of biodiesel from the oily content of marine green alga Ulva fasciata. J. Chem. Soc. Pak. 2015, 37, 1040-1046.

94. Zhuang, Y.; Guo, J.; Chen, L.; Li, D.; Liu, J.; Ye, N. Microwave-assisted direct liquefaction of Ulva prolifera for bio-oil production by acid catalysis. Bioresour. Technol. 2012, 116, 133-139. [CrossRef]

95. Kong, X.; Wu, S.; Li, X.; Liu, J. Microwave-assisted liquefaction of Ulva prolifera over $\mathrm{Fe}_{2} \mathrm{O}_{3}$-modified $\mathrm{HY}$ catalyst. J. Energy Eng. 2018, 144, 401-407. [CrossRef]

96. Tsubaki, S.; Oono, K.; Hiraoka, M.; Ueda, T.; Onda, A.; Yanagisawa, K.; Azuma, J.-I. Hydrolysis of green-tide forming Ulva spp. by microwave irradiation with polyoxometalate clusters. Green Chem. 2014, 16, 2227-2233. [CrossRef]

97. Kim, J.; Ha, S.H. Hydrothermal pretreatment of Ulva pertusa Kjellman using microwave irradiation for enhanced enzymatic hydrolysis. Korean Chem. Eng. Res. 2015, 53, 570-575. [CrossRef]

98. Mason, T.J.; Paniwnyk, L.; Lorimer, J.P. The uses of ultrasound in food technology. Ultrason. Sonochem. 1996, 3, 253-260. [CrossRef]

99. Lavilla, I.; Bendicho, C. Fundamentals of ultrasound-assisted extraction. In Water Extraction of Bioactive Compounds; Domínguez, H., González-Muñoz, M.J., Eds.; Elsevier: Kidlington, UK, 2017; pp. 291-316.

100. Fabrowska, J.; Messyasz, B.; Szyling, J.; Walkowiak, J.; Łęska, B. Isolation of chlorophylls and carotenoids from freshwater algae using different extraction methods. Phycol. Res. 2018, 66, 52-57. [CrossRef]

101. Messyasz, B.; Michalak, I.; Łęska, B.; Schroeder, G.; Górka, B.; Korzeniowska, K.; Lipok, J.; Wieczorek, P.; Rój, E.; Wilk, R.; et al. Valuable natural products from marine and freshwater macroalgae obtained from supercritical fluid extracts. J. Appl. Phycol. 2018, 30, 591-603. [CrossRef] [PubMed]

102. Michalak, I.; Górka, B.; Wieczorek, P.P.; Rój, E.; Lipok, J.; Łęska, B.; Messyasz, B.; Wilk, R.; Schroeder, G.; Dobrzyńska-Inger, A.; et al. Supercritical fluid extraction of algae enhances levels of biologically active compounds promoting plant growth. Eur. J. Phycol. 2016, 51, 243-252. [CrossRef]

103. Yaich, H.; Garna, H.; Besbes, S.; Barthélemy, J.-P.; Paquot, M.; Blecker, C.; Attia, H. Impact of extraction procedures on the chemical, rheological and textural properties of Ulvan from Ulva lactuca of Tunisia coast. Food Hydrocoll. 2014, 40, 53-63. [CrossRef]

104. Hardouin, K.; Bedoux, G.; Burlot, A.-S.; Donnay-Moreno, C.; Bergé, J.-P.; Nyvall-Collén, P.; Bourgougnon, N. Enzyme-assisted extraction (EAE) for the production of antiviral and antioxidant extracts from the green seaweed Ulva armoricana (Ulvales, Ulvophyceae). Algal Res. 2016, 16, 233-239. [CrossRef]

105. Fleurence, J. The enzymatic degradation of algal cell walls: A useful approach for improving protein accessibility? J. Appl. Phycol. 1999, 11, 313-314. [CrossRef]

106. Bobin-Dubigeon, C.; Lahaye, M.; Guillon, F.; Barry, J.-L.; Gallant, D.J. Factors limiting the biodegradation of Ulva sp cell-wall polysaccharides. J. Sci. Food Agric. 1997, 75, 341-351. [CrossRef]

107. Konasani, V.R.; Jin, C.; Karlsson, N.G.; Albers, E. Ulvan lyase from Formosa agariphila and its applicability in depolymerisation of Ulvan extracted from three different Ulva species. Algal Res. 2018, 36, 106-114. [CrossRef]

108. Reisky, L.; Stanetty, C.; Mihovilovic, M.D.; Schweder, T.; Hehemann, J.-H.; Bornscheuer, U.T. Biochemical characterization of an Ulvan lyase from the marine flavobacterium Formosa agariphila KMM 3901T. Appl. Microbiol. Biotechnol. 2018, 102, 6987-6996. [CrossRef] [PubMed] 
109. Lin, H.C.; Tsai, W.S.; Chiu, T.H. Antioxidant properties of seven cultivated and natural edible seaweed extracts from Taiwan. J. Aquat. Food Prod. Technol. 2012, 21, 248-264. [CrossRef]

110. Robin, A.; Kazir, M.; Sack, M.; Israel, A.; Frey, W.; Mueller, G.; Livney, Y.D.; Golberg, A. Functional protein concentrates extracted from the green marine macroalga Ulva sp.; by High Voltage Pulsed Electric Fields and Mechanical Press. ACS Sustain. Chem. Eng. 2018, 6, 13696-13705. [CrossRef]

111. Polikovsky, M.; Fernand, F.; Sack, M.; Frey, W.; Müller, G.; Golberg, A. In silico food allergenic risk evaluation of proteins extracted from macroalgae Ulva sp. with pulsed electric fields. Food Chem. 2019, 276, 735-744. [CrossRef] [PubMed]

112. El-Belghiti, K.; Vorobiev, E. Modelling of solute aqueous extraction from carrots subjected to a pulsed electric field pre-treatment. Biosyst. Eng. 2005, 90, 289-294. [CrossRef]

113. Postma, P.R.; Cerezo-Chinarro, O.; Akkerman, R.J.; Olivieri, G.; Wijffels, R.H.; Brandenburg, W.A.; Eppink, M.H.M. Biorefinery of the macroalgae Ulva lactuca: Extraction of proteins and carbohydrates by mild disintegration. J. Appl. Phycol. 2018, 30, 1281-1293. [CrossRef]

114. Hamouda, R.A.; Sherif, S.A.; Ghareeb, M.M. Bioethanol production by various hydrolysis and fermentation processes with micro and macro green lgae. Waste Biomass Valoriz. 2018, 9, 1495-1501. [CrossRef]

115. Trivedi, N.; Gupta, V.; Reddy, C.R.K.; Jha, B. Enzymatic hydrolysis and production of bioethanol from common macrophytic green alga Ulva fasciata Delile. Bioresour. Technol. 2013, 150, 106-112. [CrossRef]

116. Rahimi, F.; Tabarsa, M.; Rezaei, M. Ulvan from green algae Ulva intestinalis: Optimization of ultrasound-assisted extraction and antioxidant activity. J. Appl. Phycol. 2016, 28, 2979-2990. [CrossRef]

117. Praptijanto, A.; Muharam, A.; Nur, A.; Putrasari, Y. Effect of Ethanol Percentage for Diesel Engine Performance Using Virtual Engine Simulation Tool. Energy Procedia 2015, 68, 345-354. [CrossRef]

118. Loret, E.P.; Luis, J.; Nuccio, C.; Villard, C.; Mansuelle, P.; Lebrun, R.; Villard, P.H. A low molecular weight protein from the Sea anemone Anemonia viridis with an anti-angiogenic activity. Mar. Drugs 2018, 6, 134. [CrossRef] [PubMed]

119. Härtl, K.; Denton, A.; Franz-Oberdorf, K.; Hoffmann, T.; Spornraft, M.; Usadel, B.; Schwab, W. Early metabolic and transcriptional variations in fruit of natural white-fruited Fragaria vesca genotypes. Sci. Rep. 2017, 7, 45113-45117. [CrossRef] [PubMed]

120. Loret, E.P.; Darque, A.; Jouve, E.; Loret, E.A.; Nicolino-Brunet, C.; Morange, S.; Castanier, E.; Casanova, J.; Caloustian, C.; Bornet, C.; et al. Intradermal injection of a Tat Oyi-based therapeutic HIV vaccine reduces of $1.5 \log$ copies/ml the HIV RNA rebound median and no HIV DNA rebound following cART interruption in a phase I/II randomized controlled clinical trial. Retrovirology 2016, 13, 21-32. [CrossRef] [PubMed]

121. Winter, C.; Weinbauer, M. Randomly Amplified Polymorphic DNA Reveals Tight Links between Viruses and Microbes in the Bathypelagic Zone of the Northwestern Mediterranean Sea. Appl. Environ. Microbiol. 2010, 20, 6724-6732. [CrossRef] [PubMed]

122. Angione, C.; Conway, M.; Lió, P. Multiplex methods provide effective integration of multi-omic data in genome-scale models. BMC Bioinform. 2016, 17, 83-89. [CrossRef] [PubMed]

(C) 2019 by the authors. Licensee MDPI, Basel, Switzerland. This article is an open access article distributed under the terms and conditions of the Creative Commons Attribution (CC BY) license (http://creativecommons.org/licenses/by/4.0/). 